University of Montana

ScholarWorks at University of Montana

$10-1970$

\title{
Sentiment Changes and Recreation Participation
}

Perry J. Brown

University of Montana - Missoula, perry.brown@umontana.edu

Follow this and additional works at: https://scholarworks.umt.edu/forest_pubs

Part of the Forest Management Commons

Let us know how access to this document benefits you.

\section{Recommended Citation}

Brown, Perry J., "Sentiment Changes and Recreation Participation" (1970). Forest Management Faculty Publications. 38.

https://scholarworks.umt.edu/forest_pubs/38

This Article is brought to you for free and open access by the Forest Management at ScholarWorks at University of Montana. It has been accepted for inclusion in Forest Management Faculty Publications by an authorized administrator of ScholarWorks at University of Montana. For more information, please contact scholarworks@mso.umt.edu. 


\title{
Sentiment Changes and Recreation Participation
}

\author{
by Perry J. Brown
}

If participation in recreation activities represents a choice among alternatives, then such discretion may have implications for measuring activity participation. Following is a discussion of the discretionary nature of recreation and the importance of such discretion for use projection which utilizes participation rates. It is proposed that consumer sentiment about the economy at the time participation data are collected is important in evaluating the data and activity projections.

The 1960 Outdoor Recreation Resources Review Commission projections indicated that participation in recreation activities would increase by a factor of three from 1960 to 2000 (13). More recent (1965) statistics published by the Bureau of Outdoor Recreation indicate that participation will jump four times from 1960 to 2000 . BOR has indicated that these more recent data were collected in a manner comparable with the 1960 data (5). Therefore, it is assumed that the activity increases are due to an increasing propensity to recreate rather than to gross survey errors. Without entirely discounting this assumption, it is possible to offer other explanations which might illuminate the situation. One partial explanation of the increased participation rates is based on the discretionary nature of recreation activities and the associated theory of adaptive consumer behavior.

\section{Discretionary Behavior}

Discretionary behavior is choice behavior. It is that behavior which is undertaken in relatively unconstrained situations. It is characterized by not having to be made at a given time and not being habitual. Discretion permits the individual to try new activities or to shift to other activities if he becomes satiated or bored. It also permits postponement of activity participation when the perceived costs of activity are greater than the perceived benefits.

For over twenty years The University of Michigan Survey Research Center has been studying some forms of discretionary behavior. ${ }^{1}$ The Center's studies of psychological economics have provided information demonstrating how consumer discretionary purchases change with the consumers' perceived changes in economic conditions. SRC's major discretionary behavior studies have dealt with purchases of large durables such as automobiles and household goods $(9,10,11)$.

- Perry J. Brown is a lecturer, department of forest science, and a member of the Institute for the Study of Outdoor Recreation and Tourism, Utah State University.

1. Particularly clear reports of some of this work can be found in references 9 and 10 by George Katona. 
One discretionary behavior analysis tool of the Survey Research Center is the Index of Consumer Sentiment (ICS). It summarizes changes in consumer attitudes relating to personal financial situations, general market conditions, and general economic outlook (10). These attitudes have been measured quarterly since 1952 . One score representing all three attitude areas is indexed using one quarter's score as a base (currently winter 1966). Measurement of these attitude changes has consistently permitted the prediction of sales volume of large durables six to nine months later $(10,12)$. For example, an increase in ICS usually is translated into future increased automobile sales. A decrease in ICS usually signals a future decrease in automobile sales. Prediction of changes in automobile sales represents only one example of the use of the ICS.

Participation in most recreation activities fits the criteria established to describe discretionary behavior. Recreation participation permits extensive leeway in rigor of planning. Furthermore, the functions (in a motivational sense) served by most recreation activities can be served by other recreational and non-recreational activities.

It is proposed that the relationships between sentiment and discretionary purchases apply to evaluation of outdoor recreation participation. That is, a person's willingness to buy is adaptive to changes in perceived economic states. There is an expansion of participation in good times and a lessening of participation during economic down turn. Also suggested is that a participation shift to different activities occurs with a perceived economic change.

\section{Recreation Participation}

There are several factors which may have produced the difference in ORRRC and BOR measurements. Sampling errors, interviewer biases and differences, question modifications, and changes in recreation supply are relevant. Perceived differences in the economy between the two survey periods may also have significantly influenced each period's participation rates.

The economic situation in 1960 was not perceived by consumers as desirable. Katona (10) indicated that consumer attitudes deteriorated sharply in the Spring of 1960 . A recession began in late 1960.

During 1965 the health of the economy was perceived differently than in 1960. Consumers were better off than ever before. Unemployment dropped sharply and expectations and aspirations rose greatly. In fact, in August of 1965 the ICS reached an all-time peak. Comparison of the 1960 and 1965 values shows declining sentiment in 1960 and rising sentiment in 1965. (Table 1) But, the significance of the differences is greater than shown. Additional meaning is extracted from the 1960 and 1965 data through comparison with the range of ICS values experienced since 1952. The lowest ICS value calculated previous to winter 1970 was 78.5 . The highest value ever was 103.2. ICS values in 1960 did not signal a drastic decline in the economy. But, it is clear that sentiment in 1960 was considerably lower than in 1965 .

Data relating the effects of consumer sentiment on recreation participation are lacking. However, if recreation acts like other discretionary purchase products, part of the increased participation rates in 1965 were likely due to recreationist (consumer) perceptions of good times. In this case the difference 
TABLE 1

Index of Consumer Sentiment Values for each Quarter of 1960 AND 1965 (FALL $1956=100)$.

\begin{tabular}{lll}
\hline \multicolumn{1}{c}{ Quarter } & 1960 & 1965 \\
\hline Winter & 98.9 & 101.5 \\
Spring & 92.9 & 102.2 \\
Summer & n.a. & 103.2 \\
Fall & 90.1 & 102.6 \\
\hline
\end{tabular}

Source: Survey Research Center, The University of Michigan.

was compounded because 1960 was a period of increasingly negative conditions. If 1960 had been a statistically average year, then as great a discrepancy as occurred would not have been anticipated. But, since both 1960 and 1965 departed significantly from the average, participation rate differences were intensified.

Major impacts were likely on those activities which attracted large numbers of persons and also which are relatively expensive. Sightseeing is probably the best representative. BOR indicated that total participation in sightseeing increased by 59 percent between 1960 and 1965 (5). This increase far exceeded population growth. Such an increase would have been predicted if consumer sentiment was a contributing factor to recreation participation.

Analysis of participation in some other mass participation activities reveals additional trade-off possibilities. Total participation in activities relatively less expensive than sightseeing, like swimming and driving for pleasure, increased by 44 and 8 percent, respectively (5). The change in driving for pleasure is particularly interesting. Part of the decline in average per capita driving for pleasure occasions may have been absorbed by the per capita increase in sightseeing occasions. If consumer sentiment was a factor in participation, such a trade-off was likely.

Some other data lead to less speculation. Data showing the relationship between summer tourist (sightseeing) travel to Utah and the ICS support the assumption that consumer sentiment influences recreation participation. A possible relationship between these two variables was noted in late 1967 (3). Preceding Utah's bumper tourist year of 1966 the ICS rose sharply, and preceding the 1967 decline in tourist numbers, the Index fell dramatically.

For a large portion of the Nation's citizens a tourist trip to the West is a large discretionary purchase and, for two reasons, Utah tourism is representative of western tourism. First, the home residence distribution of Utah tourists is similar to the distribution for other intermountain states (6). Second, it has been shown that generally a tourist visit to Utah is a segment of a much longer vacation experience in the West (7).

The relationship between Utah tourism and the ICS has been examined for the past few years. Table 2 demonstrates the correspondence between the ICS and an indexed value for Utah tourism. ${ }^{2}$ Analysis was by least squares

2. Utah travel volume was indexed using 1968 travel as the base of 100 . It was also adjusted to eliminate the influence of population growth. 
TABLE 2

Index of Consumer Sentiment Fall Values and lndexed Utah Travel Volumes for the Summer Seasons (Adjusted for Population Growth), 1965-1969

\begin{tabular}{ccc}
\hline Year & $\begin{array}{c}\text { Index of Consumer } \\
\text { Sentiment* }\end{array}$ & $\begin{array}{c}\text { Index of Utah } \\
\text { Travel } \dagger\end{array}$ \\
\hline 1965 & 99.4 & 98.4 \\
1966 & 102.6 & 103.6 \\
1967 & 88.3 & 95.8 \\
1968 & 92.9 & 100.0 \\
1969 & 92.1 & 100.5 \\
\hline
\end{tabular}

* Source: Survey Research Center, The University of Michigan.

$\dagger$ Source: Gross traffic volume figures were obtained from references $1,2,4$, and 8 and adjusted and indexed by the author.

techniques with a resulting correlation coefficient $\left(\mathrm{r}^{2}\right)$ of 0.72 when using 1966 to 1969 data. ${ }^{3}$

It is clear that the volume of tourist travel changes directly with changes in consumer sentiment as measured six to nine months before actual travel. The tourist data suggest that some changes in recreation participation are related to changes in consumer sentiment.

\section{Conclusion}

Described above is one manifestation of adaptive economic behavior in which the psychological component of willingness to buy is a factor. Though time series data which clearly demonstrate this form of behavior in recreation activities are lacking, it has been shown that the form of behavior is found with other discretionary activities. Therefore, a greater examination of the effects of the perceived state of the economy on recreation participation may be due. It was not suggested that Index of Consumer Sentiment values be used directly to predict activity participation. Rather, the inference that changes in sentiment influence participation is suggested. It may not be enough to adjust one year participation rates by family income, education, occupation, place of residence, age-sex, leisure, and per capita opportunity to participate classes 4 to achieve reliable estimates when the participation rates may be a product of short run variable economic conditions. Such conditions, it has been proposed, were a factor in the change in activity participation rates noted between the 1960 and 1965 surveys.

3. $Y=45.42+.58 \mathrm{X}$ The 1965 data were omitted because the 1965 travel volume is not wholly comparable to the other traffic volumes.

4. ORRRC adjustment factors (13).

\section{References}

(1) Bradley, Iver E. and R. S. Lawson, Utah Traveler Index, Salt Lake City, Utah: Bureau of Economic and Business Research, University of Utah, 1967.

(2) — Dimensions of Utah's Travel Industry, Salt Lake City, Utah: Bureau of Economic and Business Research, University of Utah, 1969. 
(3) Brown, Perry J. and John D. Hunt, "Consumer Sentiment and Utah's Out-ofState Visitor," Utah Science, Vol. XXVIII, No. 4, (December, 1967), 119-120.

(4) - Utah Travel-Summer Quarter 1969, Logan, Utah: Utah State University, 1969.

(5) Bureau of Outdoor Recreation, Outdoor Recreation Trends, Washington, D. C.: Bureau of Outdoor Recreation, 1967.

(6) Goeldner, C. R., Travel Trends in the United States and Canada, Boulder, Colorado: Bureau of Business and Economic Research, University of Colorado, 1968.

(7) Hunt, John D. and Perry J. Brown, Consumer Decisions Affecting Vacation Patterns, Logan, Utah: Utah State University, 1967.

(8) - Expenditures of the 1968 Utah Summer Motor Vehicle Tourist, Logan, Utah: Utah State University, 1969.

(9) Katona, George, The Powerful Consumer, New York: McGraw-Hill Book Company, Inc., 1960.

(10) - The Mass Consumption Society, New York: McGraw-Hill Book Company, Inc., 1964.

(11) _- "Consumer Behavior: Theory and Findings on Expectations and Aspirations," American Economic Review, Vol. LVIII, (May, 1968), 19-30.

(12) Muller, Eva, "Ten Years of Consumer Attitude Survey: Their Forecasting Record," Journal of the American Statistical Association, Vol. LVIII, (December, 1963), 899-917.

(13) Outdoor Recreation Resources Review Commission, Prospective Demand for Outdoor Recreation, ORRRC Study Report 26, Washington, D. C.: U. S. Government Printing Office, 1962. 